\title{
Analisis Kemampuan Berpikir Kritis Matematis Siswa Pada Materi Pola Bilangan
}

\author{
Kartin Usman', Hamzah B. Uno ${ }^{2}$, Franky A Oroh ${ }^{3}$, Raviani \\ Mokolinug* $^{*}$
}

1,2,3Jurusan Matematika, Fakultas MIPA, Universitas Negeri Gorontalo,

Jl. Prof. Dr. Ing. B. J. Habibie, Tilongkabila, Kabupaten Bone Bolango, Gorontalo 96119, Indonesia

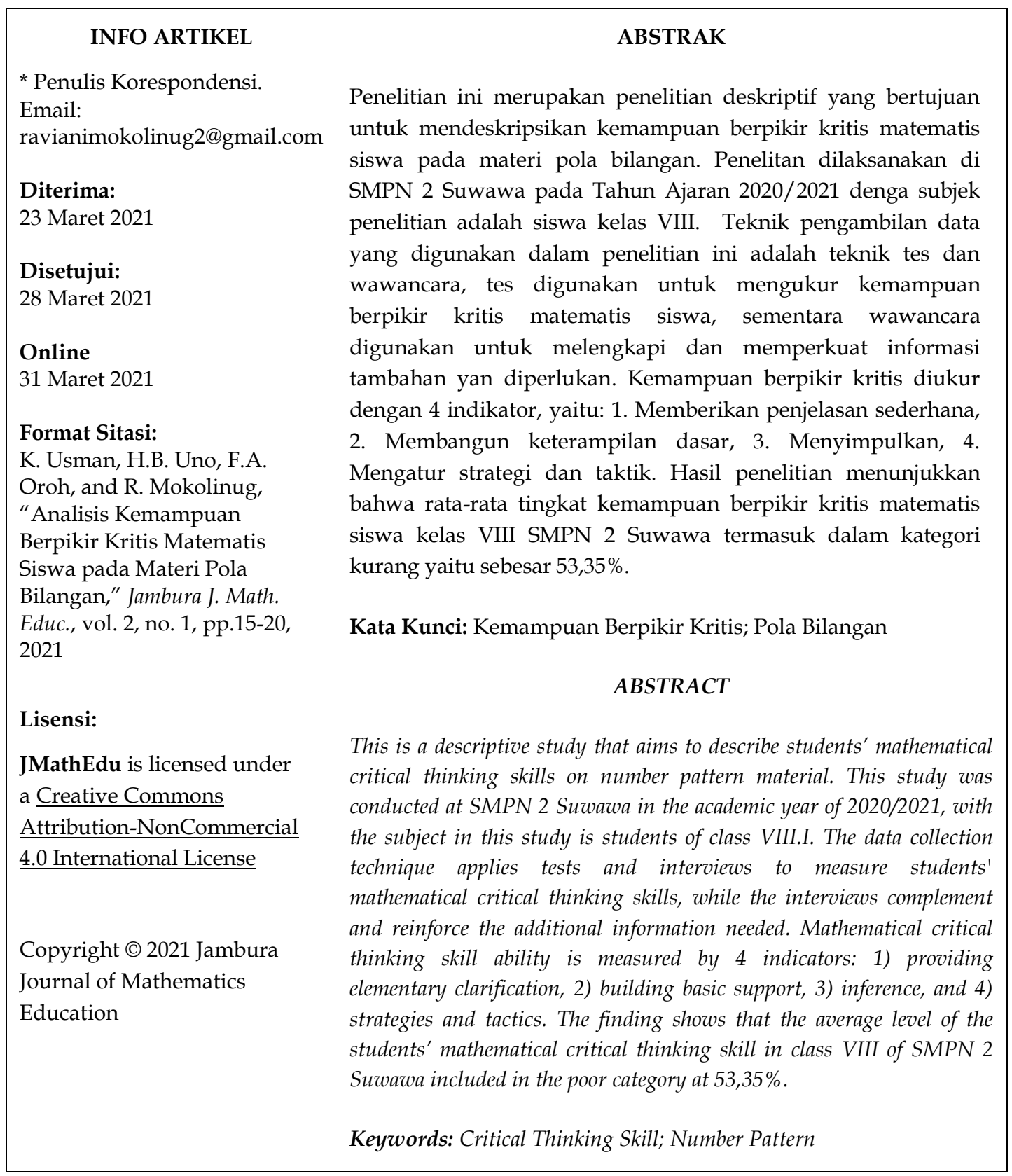


K. Usman, dkk | Analisis Kemampuan Berpikir Kritis Matematis Siswa pada Materi Pola...

\section{Pendahuluan}

Berpikir kritis dalam pembelajaran bertujuan untuk mengarahkan siswa untuk memiliki cara berpikir yang terstruktur dan cerdas dalam mengorganisasikan antar konsep untuk memecahkan masalah. Kurangnya implementasi berpikir kritis dalam pembelajaran matematika telah menyebabkan rendahnya kemampuan berpikir kritis siswa. Jean Piaget berpendapat bahwa proses berfikir manusia sebagai suatu perkembangan yang bertahap dari berfikir intelektual konkrit ke absrak berurutan melalui empat periode. Periode berfikir yang dikemukakan piaget adalah: periode sensori motor (0-1,5tahun), periode pra-operasional (1,5-6 tahun), periode operasional konkrit (6-12 tahun), periode operasi formal (12 tahun ke atas) hal in dapat dilhat dalam [1]. Berdasarkan apa yang telah dikemukakan oleh Jean Piaget maka peneliti akan meneliti pada periode operasi formal. Siswa yang termasuk dalam kategori periode operasi formal yang akan diteliti adalah siswa kelas VIII.

Berdasarkan wawancara dengan salah seorang guru SMPN 2 Suwawa diperoleh keterangan bahwa tujuan pembelajaran matematika belum tercapai secara optimal disekolah tersebut, salah satunya kemampuan berpikir kritis matematis siswa. Hal tersebut dapat terlihat dari beberapa gejala yaitu: Siswa kurang mampu dalam merumuskan dan menyajikan masalah yang berkaitan dengan masalah yang ada, hasil pekerjaan siswa belum menunjukkan sistematika penyelesaian soal, siswa tidak dapat menarik kesimpulan dari masalah yang ada .

Berbagai penelitian yang berkaitan dengan kemampuan berpikir kritis matematis misalnya, sejauh ini banyak dikaji yang berkaitan dengan kecenderungan siswa ditemukan pada [2]-[4]. Demikian juga dengan upaya untuk melakukan analisis terhadap kemampuan berpikir kritis matematis siswa untuk mencari solusi dari suatu permasalahan seperti yang ada pada [5]-[7]. Disamping itu. Terdapat beberapa penelitian yang berkaitan dengan upaya untuk meningkatkan kemampuan berpikir kritis matematis siswa yang dapat dlihat pada [8]-[11]. Adapun penelitian yang terkait dengan materi pola bilangan dapat ditemukan pada [12][13]. Dari banyaknya penelitian yang disebutkan sebelumya belum ada penelitian yang membahas mengenai kemampuan berpikir kritis matematis siswa terkhusus pada materi pola bilangan. Kemampuan dasar siswa memiliki peranan yang penting untuk digali dan dikebangkan untuk dapat memaksimalkan hasil belajar pada topik tertentu [14], terlebih lagi dimasa pandemi Covid-19 yang menyebabkan semua pembelajaran dilakukan secara daring.

Oleh karena itu, dalam artikel ini dilakukan analisis terhadap kemampuan berpikir kritis matematis siswa pada materi pola bilangan. Penelti merasa perlu melakukan penelitian ini karena kamampuan berpikir kritis matematis adalah salah satu tujuan pembelajaran matematika yang sangat penting apalagi pada masa pandemi ini yang menyebabkan proses pembelajaran dilakukan secara daring.

\section{Metode}

Metode yang digunakan dalam penelitian ini adalah deskriptif untuk menggambarkan kemampuan berpikir kritis matematis siswa pada materi pola bilangan. Penelitian ini melibatkan 25 orang siswa sebagai sampel penelitian yang ditentukan dengan teknik purposive sampling. Data yang digunakan adalah data hasil skor tes kemampuan berpikir kritis matematis siswa yang diperoleh melalui tes essay. Data diperoleh dengan cara diberikan instrumen tes kemampuan berpikir kritis matematis dimana 
K. Usman, dkk | Analisis Kemampuan Berpikir Kritis Matematis Siswa pada Materi Pola...

sebelum disebarkan instrument tersebut di uji validitas dan reliabilitasnya. Data tes di analisis menggunakan analisis presentase dengan menggunakan rumus sebagai berikut

$$
\text { presentase }=\frac{\sum \text { skor yang diperoleh }}{\sum \text { skor maksimum }} \times 100 \%
$$

Untuk pengelompokan kemampuan berpikir kritis matematis menggunakan rentang nilai yang dipakai di sekolah SMPN 2 Suwawa yang terdiri dari 4 kategori sebagaimana ditampilkan pada Tabel 1.

Tabel 1. Kategori tingkat kemampuan berpikir kritis matematis menurut rentang nilai di SMPN 2 Suwawa

\begin{tabular}{cc}
\hline Presentase $(\%)$ & Kategori \\
\hline $94-100$ & Sangat Baik \\
$85-93$ & Baik \\
$77-84$ & Cukup \\
$0-76$ & Kurang \\
\hline
\end{tabular}

\section{Hasil dan Pembahasan}

\subsection{Deskrisi Data Hasil Penelitian}

Deskripsi data hasil penelitian dipaparkan berdasarkan indicator-indikator yang digunakan pada penelitian.

Indikator 1 : Memberikan Penjelasan Sederhana

Ditinjau dari kesuluruhan soal, perolehan skor siswa pada indikator ini mencapai skor sebesar $210(42 \%)$ dari total skor 500 yang terdiri dari 5 nomor soal. Perolehan skor siswa pada nomor 1 untuk indikator ini sebesar $44(44 \%)$, soal nomor 2 sebesar 44 $(44 \%)$, soal nomor 3 sebesar $52(52 \%)$, soal nomor 4 sebesar $36(36 \%)$, dan soal nomor 5 sebesar 34 (34\%). Berdasarkan perolehan skor tersebut dapat diketahui bahwa rata-rata skor kemampuan siswa pada indikator ini adalah 42, sehingga kemampuan siswa pada indikator ini tergolong kurang.

\section{Indikator 2: Mengembangkan Ketrampilan Dasar}

Ditinjau dari keseluruhan soal, perolehan skor siswa pada indikator ini mencapai skor sebesar $272(54,4 \%)$ dari total skor 500 yang terdiri dari 5 soal. Perolehan skor siswa pada nomor 1 untuk indikator ini sebesar $64(64 \%)$, soal nomor 2 sebesar $63(63 \%)$, soal nomor 3 sebesar 51 (51\%), soal nomor 4 sebesar 53 (53\%), dan soal nomor 5 sebesar 41 $(41 \%)$. Berdasarkan perolehan skor tersebut dapat diketahui bahwa rata-rata skor kemampuan siswa pada indikator ini adalah sebesar 54,4 sehingga kemampuan siswa pada indikator ini tergolong kurang.

Indikator 3: Menentukan Strategi dan Taktik

Ditinjau dari keseluruhan soal, perolehan skor siswa pada indikator ini mencapai skor sebesar $346(69,2 \%)$ dari total skor 500 yang terdiri dari 5 soal. Perolehan skor siswa pada nomor 1 untuk indikator ini sebesar 63 (63\%), soal nomor 2 sebesar 66 (66\%), soal nomor 3 sebesar 67 (67\%), soal nomor 4 sebesar 75 (75\%), dan soal nomor 5 sebesar 75 (75\%). Berdasarkan perolehan skor tersebut dapat diketahui bahwa rata-rata skor 
K. Usman, dkk | Analisis Kemampuan Berpikir Kritis Matematis Siswa pada Materi Pola...

kemampuan siswa pada indikator ini adalah sebesar 69,2 berdasarkan klasifikasi yang digunakan kemampuan siswa pada indikator ini tergolong kurang.

Indikator 4: Membuat Kesimpulan

Dilihat secara keseluruhan soal, perolehan skor siswa pada indikator ini mencapai skor sebesar $239(47,8 \%)$ dari total skor 500 yang terdiri dari 5 soal. Perolehan skor siswa pada nomor 1 untuk indikator ini sebesar $38(38 \%)$, soal nomor 2 sebesar $58(58 \%)$, soal nomor 3 sebesar $52(52 \%)$, soal nomor 4 sebesar 47 (47\%), dan soal nomor 5 sebesar 44 (44\%). Berdasarkan perolehan skor tersebut dapat diketahui bahwa rata-rata skor kemampuan siswa pada indikator ini adalah sebesar 47,8 ini tergolong kurang.

\subsection{Pembahasan}

Berdasarkan hasil tes kemampuan berpikir kritis matematis yang dilakukan dikelas VIII SMPN 2 Suwawa, siswa dibagi menjadi 4 kategori yaitu kategori sangat baik, baik, cukup dan kurang.

Kemampuan berpikir kritis matematis sangat baik adalah siswa mampu menyelesaikan soal dengan benar dimana siswa mampu mencapai seluruh indikator kemampuan berpikir kritis matematis. Siswa telah mampu untuk mengidentifikasi apa saja yang diketahui dan yang ditanyakan pada soal yang diberikan, siswa mampu menentukan pola dari suatu soal dengan membuat model matematis dari penyelesaian soal, mampu menentukan strategi dalam menyelesaikan soal dengan jawaban yang benar dan juga dapat menarik kesimpulan dari jawaban yang dituliskannya.

Kemampuan berpikir kritis matematis baik adalah siswa mampu menyelesaikan soal dengan benar dimana siswa mampu mencapai hampir seluruh indikator kemampuan berpikir kritis matematis. Siswa telah mampu untuk mengidentifikasi apa saja yang diketahui dan yang ditanyakan pada soal yang diberikan, untuk indikator menentukan pola dari suatu soal dengan membuat model matematis masih terdapat beberapa kesalahan yang dilakukan siswa, mampu menentukan strategi dalam menyelesaikan soal dengan jawaban yang benar dan juga dapat menarik kesimpulan dari jawaban mereka, namun masih ada siswa yang melakukan kesalahan pada sebagian soal.

Kemampuan berpikir kritis matematis cukup adalah siswa mampu menyelesaikan soal dengan benar dimana siswa mampu mencapai sebagian indikator kemampuan berpikir kritis matematis. Siswa telah mampu untuk mengidentifikasi apa saja yang diketahui dan yang ditanyakan pada soal yang diberikan tetapi masih ada beberapa siswa yang tidak menuliskannya, untuk indikator menentukan pola dari suatu soal dengan membuat model matematis dari penyelesaian soal masih terdapat beberapa kesalahan yang dilakukan siswa, menentukan strategi dalam menyelesaikan soal serta dapat menjawab soal dengan jawaban yang benar dan juga dapat menarik kesimpulan dari jawaban mereka namun ada yang tidak menuliskannya.

Kemampuan berpikir kritis matematis kurang adalah siswa yang tidak menyelesaikan soal dengan benar, dan ada beberapa soal yang tidak dijawab. Diketahui bahwa lebih banyak siswa berada pada kategori kurang karena banyak jawaban yang tidak lengkap atau kurang tepat, kebanyakan siswa tidak menjawab indikator pertama yaitu menuliskan diketahui dan yang ditanyakan, dan juga masih banyak yang mengalami kesulitan menentukan pola dari suatu barisan sehingga capaian skor tidak ideal, serta masih banyak juga yang tidak menuliskan kesimpulan. 
K. Usman, dkk | Analisis Kemampuan Berpikir Kritis Matematis Siswa pada Materi Pola...

Masing-masing siswa dalam kategori kemampuan berpikir kritis yang baik mempunyai perolehan skor yang berbeda pada tiap-tiap indikator, begitu juga kelompok siswa yang termasuk dalam kategori cukup dan kurang, mereka juga memiliki perolehan skor yang berbeda-beda pada tiap indikator. Ada siswa yang termasuk dalam kategori kurang, namun ada indikator yang hampir mencapai skor ideal, begitu juga siswa yang termasuk kategori baik dan cukup ada beberapa orang yang capaian skornya pada indikator menarik kesimpulan masih rendah. Hal ini menunjukkan bahwa tidak semua siswa pada kelompok berpikir kritis matematis yang baik memiliki kemampuan yang tinggi juga pada semua indikator begitu juga sebaliknya.

Pada materi pola bilangan terdapat banyak soal yang berkaitan dengan masalah pada kehidupan sehari-hari, yang dalam proses menyelesaikan membutuhkan kemampuan berpikir kritis matematis. Oleh sebab itu peran guru sangat dibutuhkan untuk membantu siswa melatih dan mengembangkan kemampuan berpikir kritis matematis siswa.

\section{Kesimpulan}

Kemampuan berpikir kritis matematis siswa kelas VIII SMPN 2 Suwawa sebesar 53,35 berada pada kategori kurang. Dari seluruh jumlah responden untuk kategori sangat baik kemampuan berpikir kritis matematis ada 1 siswa, kategori baik ada 3 siswa, kategori cukup ada 3 siswa dan kategori sedang 18 siswa.

\section{Referensi}

[1] R. A. Juwantara, "Analisis Teori Perkembangan Kognitif Piaget pada Tahap Anak Usia Operasional Konkret 7-12 Tahun dalam Pembelajaran Matematika", Al-Adzka: Jurnal Ilmiah Pendidikan Guru Madrasah Ibtidaiyah., vol. 9, no.1, pp. 27-34, Jun. 2019

[2] N. A. Yunus, E. Hulukati, and I. Djakaria, "Pengaruh Pendekatan Kontekstual terhadap Kemampuan Penalaran Matematis ditinjau dari Gaya Kognitif Peserta Didik", Jambura J.Math., vol. 2, no.1, pp.30-38, Jan. 2020

[3] R. Rosmaiyadi," Analisis Kemampuan Berpikir Kritis Matematis Siswa dalam Learning Cycle 7E Berdasarkan Gaya Belajar", Jurnal Pendidikan Matematika FKIP Univ. Muhammadiyah Metro., vol.6, no.1, pp.12-19, 2017

[4] N. Yunita, T. Rosyana and H. Hendriana, "Analisis Kemampuan Berpikir Kritis Matematis Berdasarkan Motivasi Belajar Matematis Siswa SMP", Jurnal Pembelajaran Matematika Inovatif., vol.1, no.3, pp.325-332, Mei 2018

[5] S. Ismail and H. O. Bempah," Analisis Kemampuan Berpikir Kritis Matematika Mahasiswa Jurusan Pendidikan Matematika pada Mata Kuliah Kalkulus I Materi Limit Fungsi", Jurnal Entropi, vol.13, no.1, pp.7-13, Feb. 2018

[6] R. Aulia and Mukhni,"Analisis Kemampuan Berpikir Kritis Matematis Peserta Didik Kelas XI MIPA SMA Negeri 2 Padang", Jurnal Edukasi dan Penelitian Matematika., vol.7, no.4, pp.127-133, Dec. 2018

[7] G. Alexandra and N. Ratu,"Profil Kemampuan Berpikir Kritis matematis Siswa SMP dengan Graded Response Models", Jurnal Mosharafa, vol.7, no.1, pp.103-112 , Jan. 2018 
K. Usman, dkk | Analisis Kemampuan Berpikir Kritis Matematis Siswa pada Materi Pola...

[8] K. Umam,"Peningkatan Kemampuan Berpikir Kritis matematis Siswa Melalui Pembelajaran Reciprocal Teaching", Jurnal Pendidikan Matematika Indonesia., vol.3, no.2, pp.57-61, Sept.2018

[9] C. Novtiar and U. Aripin," Meningkatkan Kemampuan Berpikir Kritis Matematis dan Kepercayaan Diri Siswa SMP Melalui Pendekatan Open Ended", Jurnal PRISMA Universitas Suryakancana., vol.6, no.2, pp.119-131, Dec.2017

[10] W. Wiliawanto, M. Bernard, P. Akbar, and A. I. Sugandi,"Penerapan Strategi Pembelajaran Aktif Question Student Have untuk Meningkatkan Kemampuan Berpikir Kritis Matematik siswa SMK", Jurnal Cendekia: Jurnal Pendidikan Matematika., vol.3, no.1, pp.136-145, Mei 2019

[11] A. Sujana, R. Rifa'I, and N. Astuti,"Penerapan Strategi Konflik Kognitif untuk Meningkatkan Kemampuan Berpikir Kritis Matematis Siswa SMP", JPPM., vol.12, no.1, 2019

[12] F. Diana and A. Fauzan,"Pengembangan Desain Pembelajaran Topik Pola Bilangan Berbasis Realistic Mathematic Education (RME) di Kelas VIII SMP/Mts", Jurnal Edukasi dan Penelitian Matematika., vol.7, no.4, pp.43-52, De.2018

[13] A. I. Setyprini, A. A. Saefudin and H. Haryanto,"Pengembangan Lembar Kerja Siswa Menggunakan Pendekatan Saintifik pada Materi Pola Bilangan", AKSIOMA: Jurnal Program Studi Pendidikan Matematika., vol.9, no.9, pp.1260-1267, Dec. 2020

[14] S. Nuna, R. Resmawan, and D. R. Isa, “Identifikasi Kemampuan Koneksi Matematis Siswa Ditinjau dari Kemampuan Spasial pada Topik Prisma dan Limas," Jambura J. Math. Educ., vol. 1, no. 2, pp. 90-97, Oct. 2020. 